\title{
Notice
}

\section{Appeal to Western psychiatrists}

In the past year, considerable changes have taken place in Ukrainian psychiatry. A new Minister of Health of the Ukraine, Yuri Spizhenko, decided to promote the founding of an independent Ukrainian Psychiatric Association, and requested Dr Semyon Gluzman to initiate its founding. Dr Gluzman, a psychiatrist and a well-known human rights activist, who spent ten years in camp and exile for opposing the political abuse of psychiatry, founded the Ukrainian Psychiatric Association at the beginning of 1991.

The Ukrainian Psychiatric Association, headed by Professor Valery Kuznetsov, has many leading Ukrainian psychiatrists among its Board-members, including Dr Gluzman himself. Its goals are to turn itself into a professional psychiatric association that defends the rights of psychiatrists and the psychiatric science, improves the education of Ukrainian psychiatrists and increases the contacts between Ukrainian and foreign psychiatrists. It wants to give Ukrainian psychiatry the necessary ethical basis and end the political abuse of psychiatry. The association promotes the introduction of new laws on psychiatric help that defend and guarantee the rights of mental patients, and works for the improvement of livingconditions in psychiatric facilities in the Ukraine.

The Ukrainian Psychiatric Association, which is the only functioning psychiatric association in the Ukraine and has already some 500 members, was supported from the beginning by the Geneva Initiative on Psychiatry (formerly the International Association on the Political Use of Psychiatry).

The Geneva Initiative on Psychiatry, convinced that under the new circumstances a reform of Ukrainian psychiatry is possible, has decided to develop a full-scale project for the restructuring of
Ukrainian psychiatry. The goals of this project are in particular to improve the education of Ukrainian psychiatrists and increase their understanding of ethical aspects of psychiatry. Without proper training of psychiatrists, there are no chances that Ukrainian psychiatry will improve.

In order to assist the Ukrainian Psychiatric Association in its work to improve the education of Ukrainian psychiatrists, the Geneva Initiative on Psychiatry plans to publish Western psychiatric literature in the Ukrainian language. However, such publications take a long time. Too long to wait.

To allow rank and file Ukrainian psychiatrists to acquaint themselves with Western psychiatric literature as soon as possible, the Geneva Initiative on Psychiatry would like to provide the Ukrainian Psychiatric Association with enough literature to open psychiatric libraries in the capital Kiev and three regional centres.

The Geneva Initiative on Psychiatry is a small nonprofit-making organisation and does not have the funds to purchase these books. For that reason, we appeal to you to donate as many books as possible. Although more than one copy of each book would be perfect, any quantity is welcome. We would also be very grateful to receive copies of the British Journal of Psychiatry, or other psychiatric journals.

Books and journals should be sent to the Geneva Initiative on Psychiatry, PO Box 3754, 1001 AN Amsterdam, The Netherlands, from where they will be shipped to the Ukraine.

Finally, changes in Soviet psychiatry are possible. Please help us to bring them about.

ROBERT VAN VOREN General Secretary Geneva Initiative on Psychiatry

\section{Erratum}

Video news, Psychiatric Bulletin, July 1992, 16, 462. The correct postcode for the address for the Sir
Martin Roth Interview videotape should have been KT160QA. 